\title{
Skin lesions on different fish species caused by bacteria
}

\section{Farklı balık türlerinde bakterilerden kaynaklı deri lezyonları}

\author{
Şevki Kayış* • Akif Er \\ Recep Tayyip Erdoğan University, Faculty of Fisheries Sciences, Department of Aquaculture, 53100, Rize, Turkey \\ ${ }^{*}$ Corresponding author: aquasevki@msn.com
}

How to cite this paper:

Kayış, Ş., Er, A., 2014. Skin lesions on different fish species caused by bacteria. Ege J Fish Aqua Sci, 31(2): 55-59. doi: 10.12714/egejfas.2014.31.2.01

\begin{abstract}
Özet: Balıklarda sıklıkla rapor edilen hastalıkların semptomları benzerdir, fakat bu semptomlar değişik faktörler sonucu meydana gelmektedir. Bu çalışmada Gram negatif, sitokrom oksidaz pozitif olan bakterilerin farklı balıklarda sebep olduğu deri lezyonları sunulmuştur. Pseudoalteromonas haloplanktis ve Vibrio spp. istavritten (Trachurus mediterraneus), Chryseobacterium indologenes melek (Pterophyllum scalare) baliğından, Pseudomonas putida japon (Carassius auratus) balı̆ından ve Aeromonas sobria kaynak alabalığından (Salvelinus fontinalis) izole edilmiştir. Bakteriler hem moleküler hem da biyokimyasal metotlara gore karakterize edilmişlerdir. Doğal ve yaralı istavrit örnekleri, Türkiye'nin Doğu Karadeniz sahillerinden gırgır ve uzatma ağları ile örneklenmiştir ve özellikle bu olay ilk kez bu çalışmada rapor edilmiştir.
\end{abstract}

Anahtar kelimeler: Pseudoalteromonas haloplanktis, Chryseobacterium indologenes, istavrit

\begin{abstract}
Symptoms of many commonly reported diseases of fishes are similar, but these symptoms may occur by different factors. Different skin lesions on some fishes caused by Gram negative cytochrome oxidase positive bacteria were presented in this study. Pseudoalteromonas haloplanktis and Vibrio spp. from wild horse mackerel (Trachurus mediterraneus), Chryseobacterium indologenes from freshwater angelfish (Pterophyllum scalare) Pseudomonas putida from goldfish (Carassius auratus) and Aeromonas sobria from brook trout (Salvelinus fontinalis) were isolated. Also, bacteria were characterized both phenotypic and molecular methods. Wild and injured T. mediterraneus samples were captured with purse seine operation and gill net at the coast of Eastern Black Sea of Turkey and particularly, the phenomena was reported for the first time in the study.
\end{abstract}

Keywords: Pseudoalteromonas haloplanktis, Chryseobacterium indologenes, horse mackerel

\section{INTRODUCTION}

Fish are sensitive to a wide variety of bacterial pathogens. Different pathogenic and opportunistic bacteria are the cause of high mortalities on fish in aquatic systems. Enteric red mouth disease (Yersinia ruckeri), motile Aeromonas septicaemia (Aeromonas hydrophila, A. sobria, A. veroni, A. cavia), bacterial kidney disease (Renibacterium salmoninarum), vibriosis (Listonella anguillarum), columnaris disease (Flavobacterium columnaris) are important and wellknown bacterial fish diseases (Austin and Austin, 2007).

The most commonly reported diseases symptoms of fishes are similar, but these symptoms may occur by different factors. Such as, unilateral or bilateral exophthalmia is very common external symptom in many fish. This symptom may occurred by Philasterides dicentrarchi (ciliate) (Kayis et al, 2011), Hoferellus cyprini (myxozoan) (Grossheider and Körting, 1992), Renibacterium salmoninarum and Aeromonas hydrophila (bacteria) on fish. Therefore, determination of diseases agents need to perform detailed studies (Lasee, 1995).

External signs of fish diseases are highly wide and variable. Dark coloration, exophthalmia, haemorrhages on fins or skin, fin erosions some of the most remarkable external fish diseases symptoms (Noga, 2010). Aeromonas hydrophila, Yersinia ruckeri, Pseudomonas putida, P. luteola, Vibrio anguillarum, Flavobacterium columnaris, Edwardsiella tarda are the most reported bacterial fish pathogens deal with skin lesions and fin erosions (Lasee, 1995; Altinok et al., 2006; Altinok et al., 2007, Noga, 2010).

In this study, unusual skin lesions on some fishes caused by different bacteria Aeromonas sobria, Chryseobacterium indologenes, Pseudomonas putida, Pseudoalteromonas haloplanktis and Vibrio spp. were presented. 


\section{MATERIALS AND METHOD}

Fifty injured Trachurus mediterraneus were sampled along the coast of Black Sea in winter 2010. Five moribund Carassius auratus and 20 Pterophyllum scalare were sampled aquarium units from Recep Tayyip Erdoğan University, Faculty of Fisheries Sciences and 10 Salvelinus fontinalis were sampled from fish farms located Eastern Black Sea in Turkey in April 2010. Fish were examined for parasites and bacteria. The lesions of fish skin, kidney, spleen and liver of fishes were sampled bacteriological and bacteria were aseptically streaked on salted $(1 \%) /$ normal tryptic soy agar (TSA) and thiosulfate citrate bile sucrose agar (TCBS).

The medium incubated at $23.5 \pm 1.5^{\circ} \mathrm{C}$ temperature and then pure cultured colonies were phenotypic characterized by API 20NE and API 20E (Biomerieux, Marcy l'Etoile, France) according to "instruction for use". API $20 \mathrm{E}$ Incubated at $36^{\circ} \mathrm{C}$ $\pm 2^{\circ} \mathrm{C}$ for $18-24$ hours, API $20 \mathrm{NE}$ incubated at $29^{\circ} \mathrm{C} \pm 2{ }^{\circ} \mathrm{C}$ 24 hours. Before the biochemical application, cytochrom oxidase, catalase, growth properties at the different temperature $\left(4,35,40^{\circ} \mathrm{C}\right)$, Gram stain, motility tests (in microscop) and glutamate starch phenol red agar (GSP) were practiced on the bacteria (Table 2). For the molecular characterization of the bacteria, DNA extraction of the isolated bacteria from fish and purification were performed by Ausubel et al. (1993) and Altinok et al. (2001).

To identify bacteria that isolated on the skin and other tissues of fishes, universal primers (27 F 5' AGA GTT TGA TCC TGG CTC AG-3', 1492 R 5' GTT TAC CTT GTT ACG ACT T-3') specific for $16 S$ rRNA gene of eubacteria were used. The products of the PCR were directly sequenced at
Macrogen Inc. (Seoul, South Korea) and results were compared by BLAST (http://www.ncbi.nlm.nih.gov).

Water temperatures were determined as fallows; seawater and fish farm water temperature was $9 \pm 0.8^{\circ} \mathrm{C}$ in December (sea water temperature was measured twice, 8.2 and $9.8^{\circ} \mathrm{C}$ in December) and $12 \pm 0.5^{\circ} \mathrm{C}$ (water temperature was measured twice, 11.5 and $12.5^{\circ} \mathrm{C}$ in April) respectively. Also aquarium water temperature was $25^{\circ} \mathrm{C}$.

\section{RESULT}

Five different bacteria isolated from the skin of moribund fishes and all bacteria characterized as cytochrom oxidase positive, Gram negative and motile. The bacteria were not isolated from internal organs except for Salvelinus fontinalis and Carassius auratus tissues. Large yellow colonies were observed in TCBS agar inoculated from the Trachurus mediterraneus and white and pale orange colonies (Figure 1) were observed in the TSA. The all bacteria were identified according to the API 20NE, API 20E and molecular method (PCR). All bacteria, identified from fishes, area of lesion on fishes and all characters of bacteria explained in Table 1 and Table 2.

Externally, infected T. mediterraneus had advanced skin lesion on the behind of the head (Figure 2). Similarly, large and deep skin lesion was observed on the head of $C$. auratus (Figure 3). Unlike the two described lesion, more widespread but had little diameter skin lesion was observed on $P$. scalare (Figure 4). Also deep lesion and severe tissue erosion were observed on the caudal peduncle of $S$. fontinalis (Figure 5).

Table 1. Bacteria, fish species and isolated area of bacterial pathogens from fish.

\begin{tabular}{|l|l|l|}
\hline Fish Species & Bacteria & Isolated area \\
\hline $\begin{array}{l}\text { Goldfish } \\
\text { (Carassius auratus) }\end{array}$ & -Pseudomonas putida & Head, liver \\
\hline $\begin{array}{l}\text { Angelfish } \\
\text { (Pterophyllum scalare) }\end{array}$ & -Chryseobacterium indologenes & All body of fish \\
\hline $\begin{array}{l}\text { Brook trout } \\
\text { (Salvelinus fontinalis) }\end{array}$ & $\begin{array}{l}\text {-Aeromonas sobria } \\
\text { Horse mackerel } \\
\text { (Trachurus mediterraneus) }\end{array}$ & $\begin{array}{l}\text { Caudal peduncle, } \\
\text { Kidney, liver, spleen }\end{array}$ \\
\hline
\end{tabular}


Table 2. All characters of bacteria isolated from fish. Molec. Ch.; molecular characterization, NA; not application, Color in Medium; GSP; glutamate starch phenol red TSA; tryptic soy agar, TCBS; thiosulfate citrate bile sucrose.

\begin{tabular}{|c|c|c|c|c|c|}
\hline Tests & Pseudomonas putida & $\begin{array}{l}\text { Chryseobacterium } \\
\text { indologenes }\end{array}$ & Aeromonas sobria & $\begin{array}{l}\text { Pseudoalteromonas } \\
\text { haloplanktis }\end{array}$ & Vibrio spp. \\
\hline Molec. Ch. & $99.7 \%$ & $96 \%$ & $97 \%$ & $98 \%$ & $96 \%$ \\
\hline API 20E Profile & NA & NA & NA & NA & 7316105 \\
\hline API 20NE Profile & $\begin{array}{l}0142457 \\
(99.8 \%)\end{array}$ & $\begin{array}{l}2650205 \\
(99.9 \%)\end{array}$ & $7136755(98.4 \%)$ & NA & 3444146 \\
\hline Cyt. Oxidase & + & + & + & + & + \\
\hline Catalase & + & NA & + & + & + \\
\hline Temp. $\left({ }^{\circ} \mathrm{C}\right)$ & & & & & \\
\hline 4 & + & + & + & - & - \\
\hline 35 & + & + & + & + & + \\
\hline 40 & + & - & NA & + & + \\
\hline Gram stain & - & - & - & - & - \\
\hline Motility & + & - & + & + & + \\
\hline $\begin{array}{l}\text { Col. in Med. } \\
\text { GSP }\end{array}$ & Violet & NA & Yellow & NA & NA \\
\hline TSA & Cream & Orange & Cream & White & Cream/White \\
\hline TCBS & NA & NA & NA & NA & Yellow \\
\hline
\end{tabular}

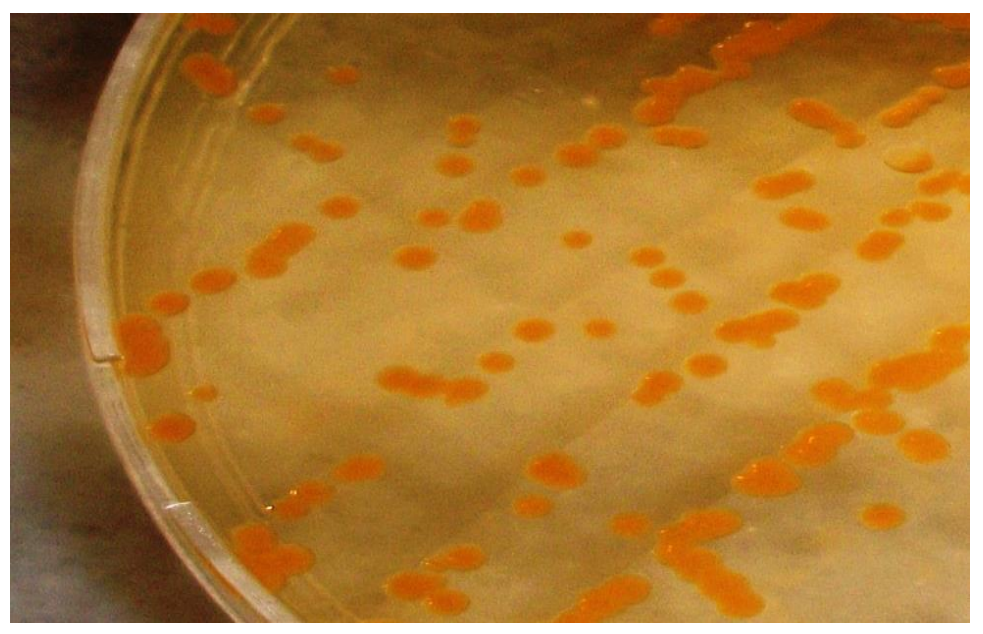

Figure 1. Colony of Chryseobacterium indologenes on TSA isolated from Pterophyllum scalare 


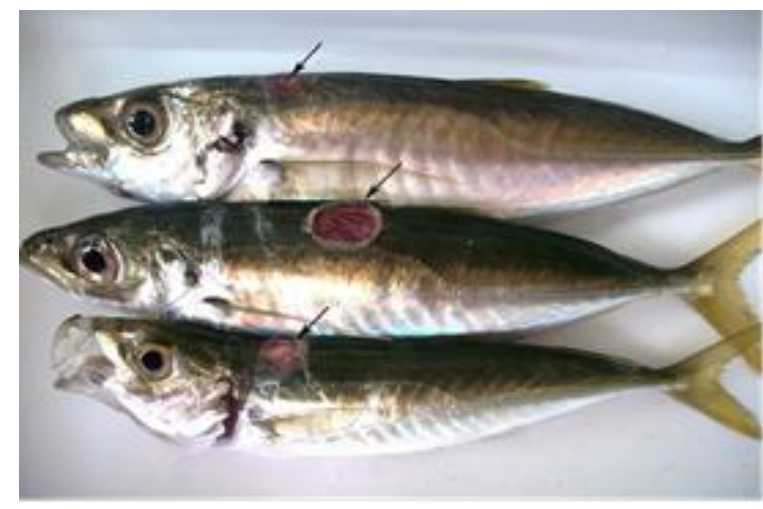

Figure 2. Deep lesions on the skin of Trachurus mediterraneus caused by Vibrio spp. and Pseudoalteromonas haloplanktis.

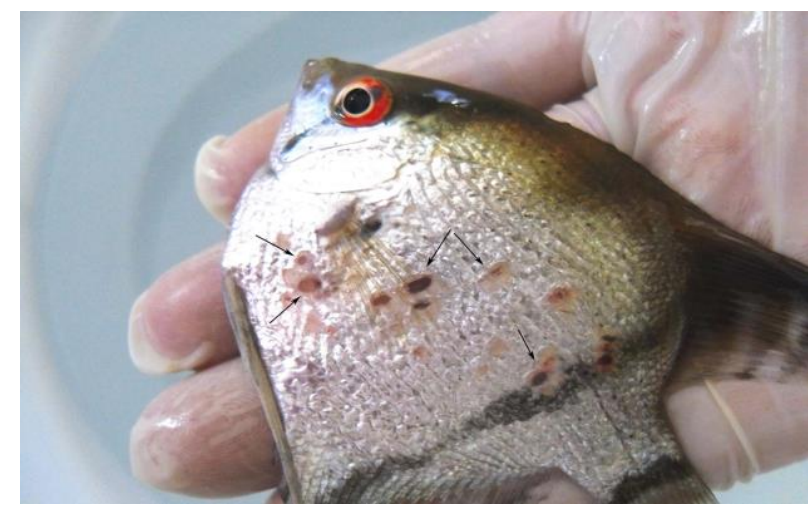

Figure 4. Multiple and widespread lesions on Pterophyllum scalare caused by Chryseobacterium indologenes.

\section{DISCUSSION}

Bacteria isolated from fish have different biochemical and pathogenic characteristics. Many bacteria and their internal and external effects on reared and wild fish have been reported by many researchers. Bacterial pathogens and their antibiotic resistant genes on reared horse mackerel (Trachurus mediterraneus) were studied in the Black Sea in Turkey (Boran et al., 2013). The study demonstrated that several Gram negative bacterial species including Aeromonas hydrophila, Vibrio vulnificus, Bulkholderia cepacia, Photobacterium damselae damselae and Vibrio alginolyticus were isolated from cultured fish. And also externally, affected fish had dark pigmentation, ascites and, petechial hemorrhage on the abdomen in the study. Unlike the previous study, present study show that mix infections of Pseudoalteromonas haloplanktis and Vibrio spp. was isolated from wild fish population with severe skin lesions.

Many of the bacteria isolated from ornamental fish are opportunists (Love et al. 1981). But some of the bacteria including Aeromonas hydrophila, A. sobria, Citrobacter freundii, Photobacterium damselae damselae, Pseudomonas aeruginosa, $P$. fluorescens, Vibrio anguillarum, V. harveyi and

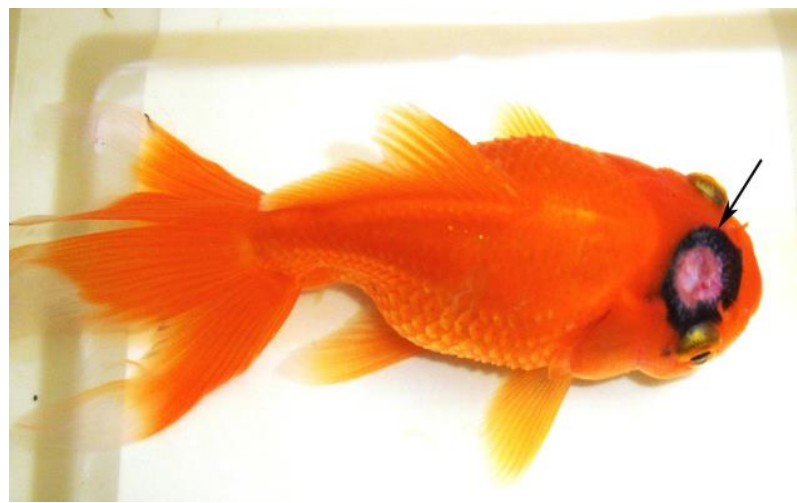

Figure 3. Deep and black ring-shape lesion on the skin of Carassius auratus caused by Pseudomonas putida.

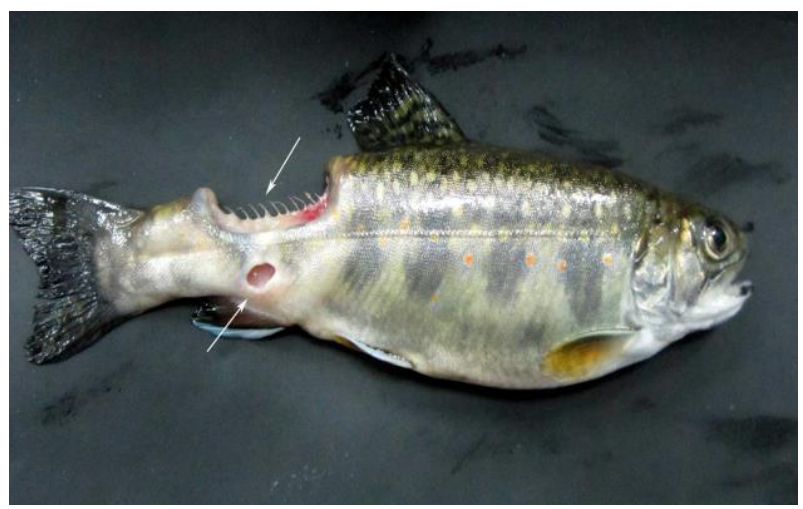

Figure 5. Deep lesion and severe tissue erosion on Salvelinus fontinalis caused by Aeromonas sobria.

V. parahaemolyticus are pathogenic in unsuitable conditions. Continuously a new species of bacteria have been reported from different fish species. In this context, Chryseobacterium indologenes isolated from diseased yellow perch (Perca flavescens) with skin lesions (Pridgeon et al., 2013). Similarly, we observed that $C$. indologenes cause multiple lesions on angelfish but mortality on fish was not observed. This circumstance may cause due to slow growth feature of the bacteria.

Goldfish (Carassius auratus) is the most common reared ornamental fish species. Therefore many disease cases of the species were reported by different paper in all over the world (Crouse-Eisnor et al., 1985; Ostland et al., 1989; Yildiz and Kumantas, 2002; Chanda et al., 2011; Kayis et al., 2013). Particularly, Aeromonas hydrophila was reported by CrouseEisnor et al. (1985), from skin surface of goldfish. Pseudomonas putida is an opportunistic human pathogen (Martino et al., 1996) and it is not a common pathogen in aquaculture and was only isolated from ayu, Plecoglossus altivelis altivelis and yellowtail, Seriola quinqueradiata, in Japan (Kusuda and Toyoshima, 1976; Muroga, 1990; 
Wakabayashi et al., 1996). Outside of Japan, P. putida infection in fish (rainbow trout, Oncorhynchus mykiss) was reported in Turkey (Altinok et. al., 2008). Similarly, this study presented that Pseudomonas putida can cause advanced damage on skin surface of goldfish.

Aeromonas salmonicida, Edwardsiella tarda, Flavobacterium branchiophilum, Nocardia spp. and Yersinia ruckeri (Bullock et al., 1978; Ostland et al., 1999, Uhland et al., 2002) were reported on brook trout (Salvelinus fontinalis). Because of to can cause skin ulcers and septicaemia, $A$.

\section{REFERENCES}

Altinok, I., Balta, F., Capkin, E., Kayis, S., 2007. Disease of rainbow trout caused by Pseudomonas luteola. Aquaculture, 273:393-397. doi: 10.1016/j.aquaculture.2007.10.025

Altinok, I., Grizzle, J.M., Liu, Z. 2001. Detection of Yersinia ruckeri in rainbow trout blood by use of polymerase chain reaction, Diseases of Aquatic Organisms 44, 29-34. doi: 10.3354/da0044029

Altinok, I., Kayis, S., Capkin, E. 2006. Pseudumonas putia infection in rainbow trout, Aquaculture 261: 850-855. doi: 10.1016/j.aquaculture.2006.09.009

Austin, B., Austin, D.A. 2007. Bacterial Fish Pathogens: Diseases of Farmed and Wild Fish, 4th ed. Praxis Publ. Ltd., Chichester, UK.

Ausubel, F.M., Brent, R., Kingston, R.E., Moore, D.D., Seidman, J.G., Smith, J.A., Struhl, K. 1993. Current Protocols in Molecular Biology, Wiley and Sons, New York.

Boran, H., Terzi, E., Altinok, I., Capkin, E., Bascinar, N. 2013. Bacterial Diseases of Cultured Mediterranean Horse Mackerel (Trachurus mediterraneus) in Sea Cages, Aquaculture, 396-399: 8-13. doi: 10.1016/.aquaculture.2013.02.025

Bullock, G.L., Stuckey, H.M., Shotts, E.B. 1978. Enteric redmouth bacterium: comparison of isolates from different geographic areas, Journal of Fish Diseases 1:351-356. doi: 10.1111/j.1365-2761.1978.tb00039.x

Chanda, M., Paul, M., Maity, J., Dash, G., Gupta, S.S., Patra, B.C. 2011. Ornamental fish goldfish, Carassius auratusand related parasites in three districts of West Bengal, India. Chronicles Young Scientists, 2:51-54 doi: 10.4103/2229-5186.79351

Crouse-Eisnor, R.A., Cone, D.K., Odense, P.H. 1985. Studies on relations of bacteria with skin surface of Carassius auratus L. and Poeciloia reticulate, Journal of Fish Biology 27:395-402. doi: 10.1111/j.1095-8649.1985.tb03188.x

Grossheider, G., Körting, W. 1995. First evidence that Hoferellus cyprini (Dofl ein, 1898) is transmitted by Nais sp., Bulletin European Association Fish Pathology 12:17-20, 1992.

Kayis, S., Balta, F., Serezli, R., Er, A. 2013. Parasites on Different Ornamental Fish Species in Turkey, fisheriessciences.com 7:114-120.

Kayis, S., Yandi, I., Altinok, I., Capkin, E. 2011. Treatment by Vinegar of Philasterides dicentrarchi (Ciliophora: Scuticociliatida) Infestation in Cultured Juvenile Turbot (Psetta maxima, Israel Journal of AquacultureBamidgeh 63:627-632.

Kusuda, R., Toyoshima, T. 1976. Characteristics of a pathogenic Pseudomonas isolated from cultured yellowtail, Fish Pathology 1:133139. doi: $10.3147 /$ jsfp. 11.133

Lasee, B.A. 1995. Introduction to Fish Health Management, U.S. Fish and Wildlife Service La Crosse Fish Health Center 555, Lester Avenue Onalaska, Wisconsin, 54650. salmonicida differ from the other bacteria (Bullock et al., 1978). Aeromonas sobria and Aeromonas caviae were reported with skin lesions on Oncorhynchus mykiss (Rehulka, 2002). Aeromonas sobria was reported from cultured rainbow trout fingerlings (skin hemorrhages), gizzard shad (Dorosoma cepedianum) (liver, kidney and spleen) (Toranzo et al., 1989). Clinical signs of motile aeromonad infection are generally superficial deep skin lesions (Noga, 2010). However, $A$. hydrophila commonly reported motile Aeromonas species from fish with the regard to skin lesions. We observed that $A$. sobria can cause deep skin ulcer and severe tissue loses.

Love, M., TeebkenFisher, D., Hose, J.E., Farmer, J.J., Fanning, G.R. 1981. Vibrio damsela, a marine bacterium causes skin ulcers on the damselfish (Chromis punctipinnis), Science 214:1139-1140.

Martino, R., Martínez, C., Pericas, R., Salazar, R., Sola, C., Brunet, S., Sureda, A., Domingo-Albos, A. 1996. Bacteremia due to glucose nonfermenting Gram-negative bacilli in patients with hematological neoplasias and solid tumors, European Journal of Clinical Microbiology Infectious Disseases, 15:610-615. doi: $10.1007 / B F 01709374$

Muroga, K. 1990. Bacterial infections in cultured fishes in Japan. In: Hirano, R., Hanyu, I. (Eds.), The Second Asian Fisheries Forum, Manila, Asian Fisheries Society 963-966.

Noga, E.J. 2010. Fish disease- diagnosis and treatment. 2nd edition. WileyBlackwell, $536 \mathrm{pp}$.

Ostland, V.E., Byrne, P.J., Lumsden, J.S., MacPhee, D.D., Derksen, J.A., Haulena, M., Skar, K., Myhr, E., Ferguson, H.W. 1999. Atypical bacterial gill disease: a new form of bacterial gill disease affecting intensively reared salmonids, Journal of Fisheries Diseaes 22:351-358. doi:10.1046/j.1365-2761.1999.00181.x

Ostland, V.E., Ferguson, H.W., Stevenson, R.M.W. 1989. Case report: bacterial gill disease in goldfish Carassias auratus, Diseases of Aquatic Organisms 6: 179-184, 2010. doi:10.3354/dao006179

Pridgeon, J.W., Klesius, P.H., Garcia, J.C. 2013. Identification and virulence of Chryseobacterium indologenes isolated from diseased yellow perch (Perca flavescens), Journal of Applied Microbiology 114:636-43. doi: 10.1111/jam.12070

Rehulka, J. 2002. Aeromonas causes severe skin lesions in rainbow trout (Oncorhynchus mykiss): Clinical Pathology, Haematology and Biochemistry, Acta Veterinaria Brno 71:351-360. doi:10.2754/avb200271030351

Toranzo, A.E., Baya, A.M., Romalde, J.L., Hetrick, F.M. 1989. Association of Aeromonas sobria with mortalities of adult gizzard shad, Dorosoma cepedianum Lesueur, Journal of Fish Diseases 12:439-448. doi: 10.1111/j.1365-2761.1989.tb00555.x

Uhland, F.C., Hélie, P., Higgins, R. 2000. Infections of Edwardsiella tarda among Brook trout in Quebec, Journal of Aquatic Animal Health 12:7477. doi: 10.1577/1548-8667(2000)012<0074:IOETAB>2.0.CO;2

Wakabayashi, H., Sawada, K., Ninomiya, K., Nishimori, E. 1996. Bacterial hemorrhagic ascites of ayu caused by Pseudomonas sp., Fish Pathology 31:239-240. doi:10.3147/jsfp.31.239

Yıldız, K., Kumantas, A. 2002. .Argulus foliaceus Infection in a Goldfish (Carassius Auratus), Israel Journal of Vet Med 57:118-120. 